\title{
SH2B3 wt Allele
}

National Cancer Institute

\section{Source}

National Cancer Institute. SH2B3 wt Allele. NCI Thesaurus. Code C102803.

Human SH2B3 wild-type allele is located in the vicinity of 12 q24 and is approximately 46

$\mathrm{kb}$ in length. This allele, which encodes SH2B adapter protein 3 , is involved in signal

transduction. Mutation of the gene is associated with susceptibility to both celiac disease type 13 and insulin-dependent diabetes mellitus. 